\title{
US space scientists rage over axed projects
}

Proposed cuts to NASA's science budget have unleashed a storm of anger from US astronomers and planetary researchers, who say the reductions would cause irreparable harm and drive young people from the field.

Under a NASA budget unveiled on 6 February (see Nature 439, 644; 2006), growth in science spending between 2007 and 2010 would be slashed by $17 \%$. The budget proposed by President George W. Bush has yet to be approved by Congress, but many planned projects - from planet searches to a Mars sample return, as well as scores of individual research grants - are likely to be scrapped (see 'Some cuts proposed at NASA').

Planetary scientist Alan Boss of the Carnegie Institution of Washington says the cuts would devastate US space science - just as physics was jolted when the Superconducting Super Collider was cancelled in 1993, after $\$ 2$ billion had been spent on it. ${ }^{\alpha}$ High energy physics never quite recovered from that."

\section{SOME CUTS PROPOSED AT NASA}

Space Interferometry Mission to map stars Terrestrial Planet Finder

USA, searching for gravitational waves

Constellation $X$, a group of $X$-ray satellites Mars Sample Return

NuSTAR, a high-energy $X$-ray satellite

Europa mission
Scientists appreciate that NASA's administrator, Mike Griffin, is struggling to balance his books. Griffin explained during the budget press conference that the science cuts were necessary to pay for shuttle flights required to complete the International Space Station. "It's what we needed to do," he said regretfully.

But Jonathan Lunine, a planetary scientist at the University of Arizona, Tucson, sums up the view of many when he says he finds it "puzzling and frustrating" that NASA would divert money from science, widely considered its most productive enterprise, to keep the aged space shuttles flying. "It seems that NASA is trying to capitalize on its failures rather than its successes," says Lunine.

Particularly hard hit is the search for new planets, a field that appeals to young scientists, says Charles Beichman of the California Institute of Technology, Pasadena. NASA could keep developing technologies for the Terrestrial Planet Finder (TPF) mission given just $\$ 10 \mathrm{mil}$ lion next year, he says. Instead, the TPF's budget will be wiped out. NASA claims the mission is "deferred indefinitely", says Beichman. "The fact is, they are cancelling the TPF. They are breaking up the technology team."

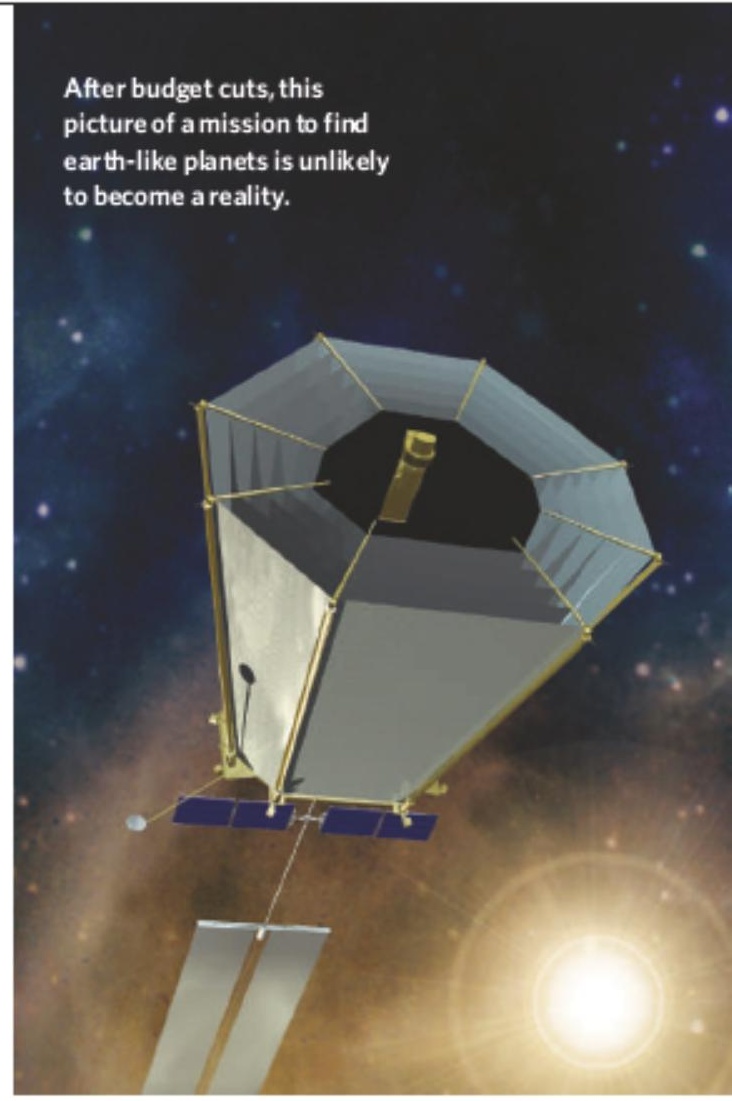

There is fury not just at the size of the cuts, but athow they were decided and announced to the science community. Heidi Hammel, a planetary researcher with the Space Science Institute in Boulder, Colorado, says that NAS A's advisory council was not operating during much of last year and so "there was absolutely no way to know how these decisions had been made. It's sort of like a black hole over there."

\section{Disgraced cloner's ally is cleared of misconduct}

Gerald Schatten was the Western face of Woo Suk Hwang's stem-cell team, which was recently exposed for faking the results of cloning experiments. On 10 February, Schatten was cleared of misconduct by his university, but chided for taking so much credit for research in which he was barely involved.

The University of Pittsburgh in Philadelphia decided to investigate Schatten in December after claims in a Science paper that he had co-authored with Seoul National University's Hwang turned out to be false (see W. S. Hwangetal. Science
308, 1777-1783; 2005 and Nature $438,718 ; 2005)$. Schatten was senior author on the paper, and his gus hing praise of Hwang's research was instrumental in raising the South Korean team'sprofile in the United States and els ewhere.

The full report has not been released, butin a public summary, the six anonymous investigators conclude that there is no evidence that Schatten knew about the fraud taking place in Hwang's lab, and they applaud Schatten for taking swift action when he became corvinced that Hwang's team had obtained eggs unethically, to create the world's firststem-cell line from a cloned human embryoback in 2004. But they are less pleased with Schatten's decision toname himself senior author on a paperfor which his only contribution was editorial.

The summary also points out that Schatten signed a coverletter for the 2005 Sdience paper claiming that all 25 authors of the paper hadread and approved of the manuscript, when very few of them probably had. And it notes that Schatten's co-authorship of a 2005 Nature paper (see B.C. Lee et al.
Nature 436,641; 2005) reporting the first cloned dog, Snuppy, was based solely on the dubious suggestion "that a professional photographer be engaged so that Snuppy would appear with greater visual appeal". Although stopping short of misconduct, the panel describes Schatten's actions as "research misbehaviour".

Stem-cell researchers contacted by Nature generally approve of the report and its conclusions. "Dr Schatten was as much of a victim as the scientific community," says Evan Snyder, who directs the 
